〔18〕橋かけポリビニルアルコールーグリオキシル酸 部分アセタール化物の合成

(1958 年 9 月 9 日受理)

桜田一郎*.中島章夫* ·外林秀人*

\begin{abstract}
要冒莎リビニルアルコールーグリオキシル酸部分アセタール化物の米状分子に関しては各種の溶液

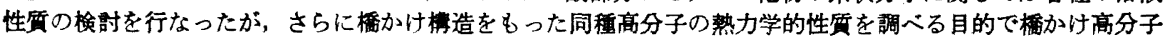
の合成を行なった。ジビニルエーテルを合成し，これを槚かけ剂として酷酸ビニルの重合を行ない，得られた

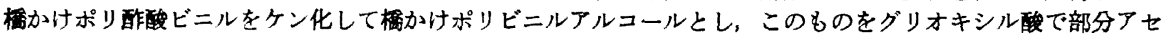

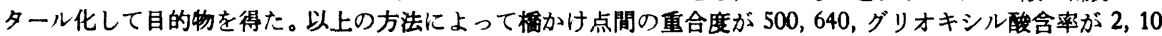
モル\%の試料を調製した。
\end{abstract}

1. 緒 言

酢酸ビニルモノマーにジビニルエーテルを添加し重合 を行なうと，下に記したようにエーテル結合を㛢かけ点 とする橋かけポリ酢酸ビニルが得られ，これをケン化す ろとエーテル結合仕安定であるから橋かけポリピニルア<smiles>C=COC=C[CH+]C(C)=O</smiles>

(酢酸ビニル) （ジビニルエーテル）

ルコールができる。このものを別報1)同様にしてグリオ キシル酸で部分的にアセタール化するときには，ポリビ ニルアルコールを主成分とする橋かけ高分子電解質が合 成できるわけである。

以下，ジピニルェーテルの合成から始め，順を追って 合成過程を述べる。

（橋かけポリ酢酸ビニル）

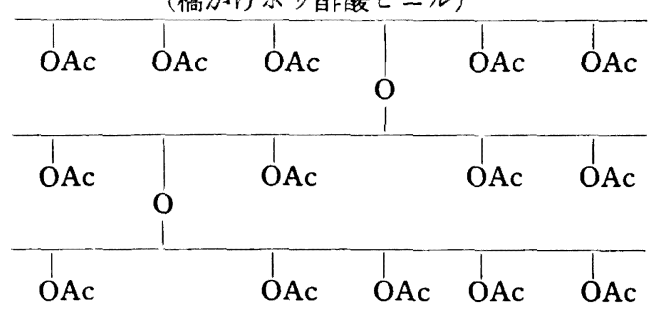

$$
\downarrow \text { ケン化 }
$$

重合

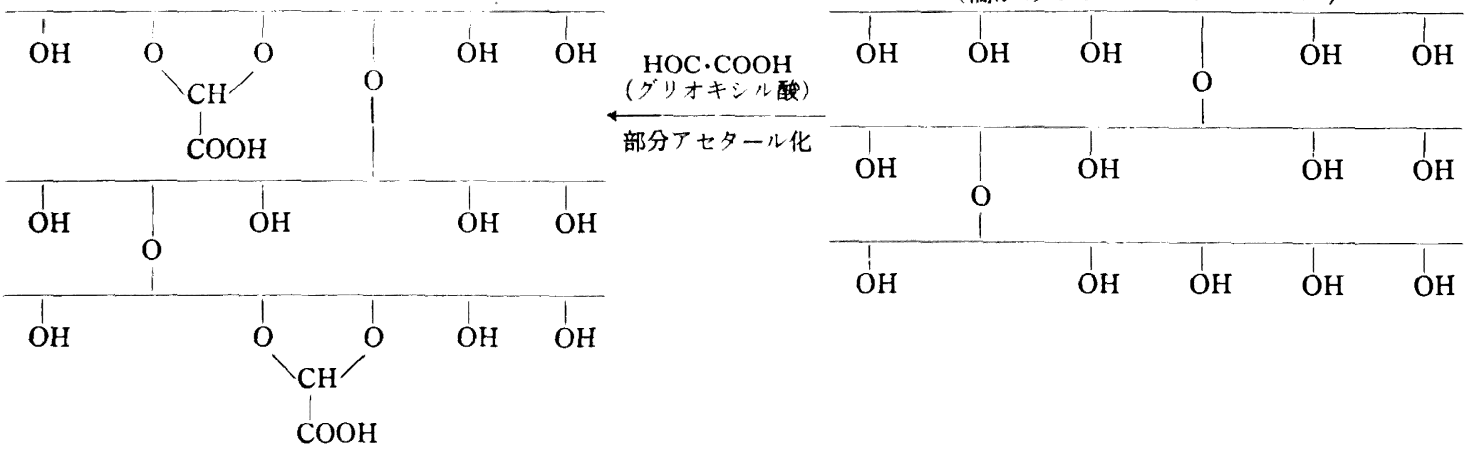

2. ジビニルエーテルの合成

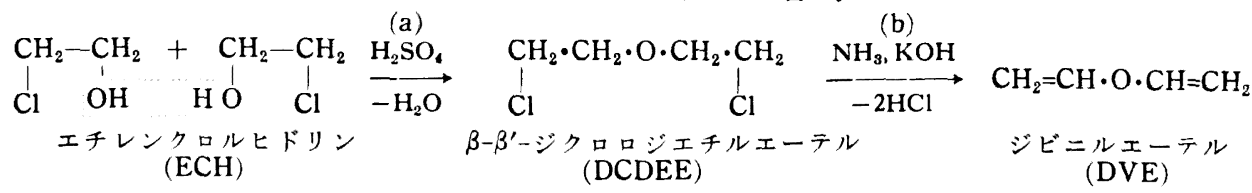

* 京都大学工学部繊維化学教室 (京都市左京区吉田) 
ジビニルェーテル (DVE) は上に示したようにェチレ ンクロルヒドリン $(\mathrm{ECH})$ を脱水縮合反応で $\beta-\beta^{\prime}$-ジクロ ロジェチルェーテル(DCDEE), これをさらに脱塩酸し て合成した。DCDEE の合成については Kamm ら²)の 研究があるが, 反応条件は明確に記载されていない。野 間, 加藤” はこの反応について検討しているので，われ われはそれらのデータを基喏にして反応条件を決定し た。第 1 表に示した実験の5ち, 番号 1〜3 は加藤らの もので番号 4 は本研究の結果である。

第 1 表 $\beta$ - $\beta^{\prime}$ ージクロロジェチルェーテルの合成

\begin{tabular}{|c|c|c|c|c|c|}
\hline 実験番号 & $\begin{array}{c}\mathrm{H}_{2} \mathrm{SO}_{4} / \\
\mathrm{ECH} \\
\text { (モル比) }\end{array}$ & $\begin{array}{c}\text { 反応浴の } \\
\text { 温度 } \\
\left({ }^{\circ} \mathrm{C}\right)\end{array}$ & 反応物の & $\begin{array}{c}\text { 反応時間 } \\
(\mathrm{hr})\end{array}$ & $\begin{array}{c}\text { 收率 } \\
\end{array}$ \\
\hline 1 & 0.17 & 195 & - & 10 & 6.0 \\
\hline 2 & 0.45 & 250 & 150 & 8 & 7.4 \\
\hline 3 & 0.30 & 250 & 150 & 10 & 16.1 \\
\hline 4 & 0.30 & 250 & 150 & 10 & 30.0 \\
\hline
\end{tabular}

実験番号 4 の詳細を記すと, ECH $563.5 \mathrm{~g}$ (7モル) と conc $\mathrm{H}_{2} \mathrm{SO}_{4} 206 \mathrm{~g}\left(2.1\right.$ モ) を丸底フラスコに入れ $\left(\mathrm{H}_{2} \mathrm{SO}_{4}\right)$ $\mathrm{ECH}$, モル比 0.3), 還流冷却器をつけて 9 10 時間加熱 する。 $\mathrm{ECH}$ の沸点は $128.6^{\circ} \mathrm{C}$ であるので椧却器の水の 温度を適当に調節し(約 $90 \sim 100^{\circ} \mathrm{C}$ ) 徐々に水を采外に導 く。約 9 時間で䄪 $1 / 3$ 容が反応系外に留出した。次には 還流冷却器をはずして反応容器にリービッヒをとりつけ 生成物を蒸留した。蒸留はフラスコ内に黒褐色の残渣 が残るまで続ける。蒸留物は炭酸ソーダ水溶液で洗浄 し, 硫酸ンーダで乾燥し,さらに精留して沸点 $178^{\circ} \mathrm{C} の$ DCDEE を得た。DCDEE は芳香のエーテル臭をもつ無 色油状の液体である。150g の DCDEE が得られた。理 論收量に対する収率は $30 \%$ であった。

次は (b)の脱塩酸反応である。これについては Ruigh ら゙の報告がある。彼らはニッケル引き銅製オートクレ

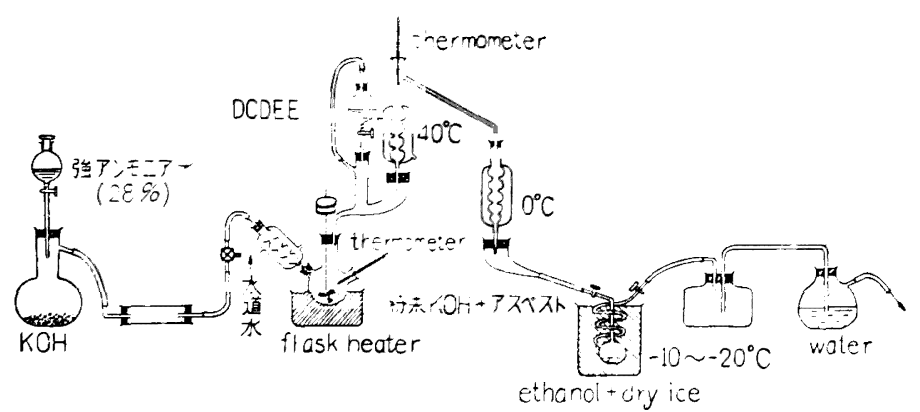

第 1 図 ジビニルェーテルの合成装置 ーブを用いているが，われわれは第 1 図に示したよ5に 銅製三ッロフラスコを使用した。詳細を以下に記す。
まず三ッロラフスコの中にアルカリを入れるのである が, 応反系中に水が存在すると生成した DVE が反応し てアセトアルデハイドをつくるので, 使用アルカリは次 のようにして調製した。すなわち $\mathrm{KOH} 100 \mathrm{~g}$ を水 $100 \mathrm{~g}$ に溶かし,さらにこれに $\mathrm{KOH} 300 \mathrm{~g}$ を少しずつ加えて ゆきこれにアスベスト粉末を加え，この混合物をフラ イパンに移し加熱し融解状態にし，さらにアスベストを 加え, 反応温度 $250^{\circ} \mathrm{C}$ 以下では融解しない程度の乾燥 状態に至らしめ,これを微粉砕しておく。このものを反 応容器に入れ, アンモニア発生器から水分を除去したア ンモニアガスを反応系内に通ずる。反応容器は頙の長い 銅製三ッロフラスコで内容物は銅製かきまぜ器で反応中 常にかきませる。このような状態にして㧈いて DCDEE を漏斗から滴下し, 反応を起させる。第 1 冷却器は約 $40^{\circ} \mathrm{C}$ に, 第 2 冷却器は $0^{\circ} \mathrm{C}$ にしておく。DVE は沸点 が $28.3 \pm 0.2^{\circ} \mathrm{C}$ であるから, 第 2 冷却器で凝縮し, さら に $-10 \sim-20^{\circ} \mathrm{C}$ に泠却された受器で完全に捕集される。 末反応の DCDEE や副成するであろらジオキサン(沸点 $100.8^{\circ} \mathrm{C}$ )などは第 1 泠却器で還流する。受器には DVE の他にアセトアルデハイド(沸点 $21^{\circ} \mathrm{C}$ ) その他の副成物 も混入してくる。受器の温度を $-30^{\circ} \mathrm{C}$ 以下にするとア ンモニアまでが液化してくるので注意を要する。捕集さ れた生成物はさらに精留しDVEを得た。結果を第 2 表 に記す。

第 2 表 DCDEE より DVE の合成

\begin{tabular}{|c|c|c|c|c|c|c|}
\hline 実験 & 添 加 & ～量 (g) & 反応 & 条件 & 留出物 & DVE \\
\hline 番号 & DCDEE & $\begin{array}{l}\text { ルカリ } \\
(\mathrm{KOH}+\boldsymbol{1} \\
\text { スベスト) }\end{array}$ & $\left({ }^{\circ} \mathrm{C}\right)^{\text {渡日 }}$ & 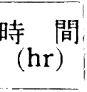 & (g) & (g) \\
\hline 1 & 50 & 300 & 250 & 6 & \multirow{2}{*}{9} & \multirow{2}{*}{3} \\
\hline 2 & 40 & 300 & 250 & 5 & & \\
\hline
\end{tabular}

以上の実験結果で収率は 7\% であった。DVE は低沸点 であるので特に反応容器のせんに留意する 必要がある。

\section{3. 酶酸ビニルとジビニルエー テルの共重合}

第 3 表に示すよらに酷酸ビ ニルに 0 5 モル\%のの DVE を添加し, さらに単量体 に対し BPOを 0.05 重量 \%加えて $70^{\circ} \mathrm{C}$ で 22 時間重合を行なわせた。反応物のア七 トンに対する溶解性を調べたところ $0.5 €$ ル\%までの添加では反応物は完全にアセ卜 ン可溶性であったが，0.5 モル\%の添加物 では一部不溶性のゲルが生成し, $1.4 \%$ 以上の添加物で は可溶性部分は存在しなっかた。したっがてこのような 
実験条件では DVE

の添加率が 0.5 モル \%付近にゲル化点が あることになる。

さらにアセトン可 溶部分について粘度 測定を行ない，次に このものをケン化し て得たポリビニルア ルコールについても 同様の測定を行なっ

第 3 表 酶酸ビニルとジビニルエーテルの共重合

\begin{tabular}{|c|c|c|c|c|}
\hline 試料番号 & 酢酸ビニル（g) & DVE (g) & $\begin{array}{c}\text { DVE/VAc } \times 100 \\
(\text { モル\%) }\end{array}$ & $\begin{array}{c}\text { ゲル部分の膨潤度 } \\
\left(30^{\circ} \mathrm{C}\right)\end{array}$ \\
\hline$S-0$ & 9.217 & 0 & 0 & 溶 解 \\
\hline$S-0.1$ & 9.211 & 0.0082 & 0.1 & 溶 解 \\
\hline$S-0.5$ & 9.217 & 0.0335 & 0.5 & 64, (一部可溶) \\
\hline$S-1.0$ & 9.217 & 0.0762 & 1.0 & 24, (一部可溶) \\
\hline $\mathrm{S}-1.4$ & 9.217 & 0.1052 & 1.4 & 17 \\
\hline $\mathrm{S}-2.4$ & 9.262 & 0.1826 & 2.4 & 8.6 \\
\hline$S-4.9$ & 9.262 & 0.3900 & 4.9 & 7.5 \\
\hline
\end{tabular}

第 4 表 非ゲル部分の粘度測定から算出した重合度（測定温度 $30^{\circ} \mathrm{C}$ )

\begin{tabular}{|c|c|c|c|c|c|c|}
\hline \multirow{2}{*}{ 試料番号 } & \multicolumn{3}{|c|}{ ポリ酢酸ビニル（アセトン溶液） } & \multicolumn{3}{|c|}{ ポリビニルアルコール（水溶液） } \\
\hline & {$[\eta](l / g)$} & $k^{\prime}$ & $P$ & {$[\eta](l / g)$} & $k^{\prime}$ & $P$ \\
\hline$S-0$ & 0.1660 & 0.4 & 4590 & 0.0740 & 0.8 & 1310 \\
\hline$S-0.5$ & 0.1320 & 0.5 & 3180 & 0.0680 & 0.7 & 1150 \\
\hline $\mathrm{S}-1.0$ & 0.0590 & 0.6 & 870 & & & \\
\hline
\end{tabular}

たところ，第 4 表のような結果が得られた。

S-0 は DVE を添加しないで重合したポリ酢酸ビニル ならびにそのヶン化物に関するものであり，重合度はヶ ン化物で 1310 ，これに対しわずかに不溶部分を含む S0.5 ではその可溶部をケン化したものの重合度は 1150 に なっている。ポリ酢酸ビニルに関する $\boldsymbol{k}^{\prime}$ 係数が橋かけ 凨含率とともに増加しているのは分岐分子の生成を示す ものであろう。

スチレンージビニルベンゼン系では DBVが $0.01 \%$ 添 加されるとゲルの生成が認められているが5)，本実験の 系ではゲル生成のためにこの 10 倍以上の橋かけ剤が必 要である。したがって VAc と DVE の反応性は前者に 比してはるかに良好でない。

ビニルモノマーAとジビニルモノマーB-B の共重合 において，反応比をそれぞれ

$$
r_{1}=\begin{aligned}
& k_{A A} \\
& k_{A B},
\end{aligned} \quad r_{2}=\begin{aligned}
& k_{B B} \\
& k_{B A}
\end{aligned}
$$

とし楅かけ点の分布が無秩序であると考える。本実験の 場合 B-B の添加量は $\mathrm{A}$ に比しはるかに小であるから，A の濃度 $[A]$ に比し B-B の濃度 $[B-B]$ は無視でき,ゲ ル化点(橋か忊剂は 4 官能性であるから1本の鎖あたり $1 / 2$ 個の橋かけ点が生じる点)における重合收率 $x_{c}$ は次 式で与えられる6)。

$$
x_{c}=\frac{1}{\bar{n}} r_{1}^{2} 2[B]
$$

澧度はいずれもモル濃度で, $\bar{n}$ は第 1 次分子の重量平均
重合度である。 数值を用いれば良いわけであるからここでは S-0 で 生成したポリ酢酸ビニルの主鎖重合度 (ケン化物ポリビ ニルアルコールの重合度, 第 4 表参照)を用い, $\bar{n}=1300$ とした。

VAc とDVEについて $r_{1}, r_{2}$ は知られていないので VAc とェチルビニルェーテルについて知られている值”

$$
r_{1}=3.0, \quad r_{2}=0
$$

を代用して $x_{c}$ を見積ってみると

\begin{tabular}{c|ccccc} 
試料番号 & $\mathrm{S}-0.5$ & $\mathrm{~S}-1.0$ & $\mathrm{~S}-1.4$ & $\mathrm{~S}-2.4$ & $\mathrm{~S}-4.9$ \\
\hline$x_{c}$ & 0.775 & 0.341 & 0.247 & 0.143 & 0.067 \\
\hline
\end{tabular}

となりここの条件で $x_{c}=1.0$ (すなわち重合率 $100 \%$ が ゲル化点)の場合の槚加け剂添加量は約 0.3 モ\%とな る。本研究の条件では重合収率はいずれも約 $90 \circ$ 。 であ るので，それから逆にゲル化点の橋かけ鼡添加率を求め ると約 0.4 モ：。とり，第 3 表の結果と良い一致を示 すことになる。このような結果から考えて VAc-DVE 系の $r_{1}, r_{2}$ はVAc-エチルビニルェーテル系のそれとは ほぼ同一であるとすることができるであろう。

\section{4. 槚かけボリビニルアルコールの調製}

前述した過程で得られた橋かけポリ酢酸ビニル(アセ トン可溶部は除去)をアルカリでケン化して橋かけポリ ビニルアルコールにした。ゲル状ケン化であるのでゲル を適当に膨潤させる必要があり，そのためケン化浴のメ 
タノールと水の比が $8: 2$ の浴で第 1 段のケン化を行な い,さらに比が 2:8のものに浸漬してケン化を完全な らしめた。用いたアルカリは $40 \% \mathrm{NaOH}$ 水溶液でこれ を当量加え,ケン化には室温で 2〜3 日かけた。ケン化物 は S-0.5 から S-1.4 までのものではドロドロした状態で 形状の保持が困難であったが，S-2.4，S-4.9 では形状は くずれていない。すなわち S-1.4 まででは網目構造が著 しく不完全であるわけである。

得られたポリマーは十分洗浄し, アルカリその他の不 純物を除去し,さらに $100^{\circ} \mathrm{C}$ で可溶性部分を水で抽出 した後, $30^{\circ} \mathrm{C}$ に戻し恒温で 7 日間水に浸漬して膨潤度 の測定を行なった。後報でも述べるよ 5 S- 2.4 とS-4.9 の水中膨潤度はそれぞれ 40 と 13.3 であった。

\section{5. 樮かけボリビニルアルコールのタリオキシル 酸による部分アセタール化}

以上で得られた橋かけポリビニルアルコールは次に前 報1に従ってグリオキシル酸で部分アセタール化した。 反応条件は水で膨潤したポリビニルアルコールを $2 N$ の $\mathrm{H}_{2} \mathrm{SO}$ 、を触媒とし， $0.1 \mathrm{~N}$ のグリオキシル酸水溶液の適当 量を加えて $60^{\circ} \mathrm{C} て ゙ 7$ 日間アセタール化反応を行なわせ た。グリオキシル酸は定量的に反応することが知られて いる゙から添加量から生成物中のグリオキシル酸含率が 求まるわけである。反底生成物は蒸留水で十分長時間透 析し, 高分子酸の形として水中で保存する。第 5 表に結 果を示す。

以上のよ5にして合成された橋かけ高分子電解質はそ の網目の長さがアセタール化前の橋かけポリピニルアル
第 5 表 橋かけポリビニルアルコールのグリ オキシル酸による部分アセタール化 $\left(2 \mathrm{~N}-\mathrm{H}_{2} \mathrm{SO}, 20 \mathrm{cc}, 60^{\circ} \mathrm{C}, 7\right.$ 日間)

\begin{tabular}{|c|c|c|c|}
\hline \multirow{2}{*}{ 試料番号 } & \multirow{2}{*}{$\begin{array}{l}\text { PVA 重量 (g) } \\
\text { (乾燥物相当) }\end{array}$} & \multicolumn{2}{|c|}{ グリオキシル酸 } \\
\hline & & $\begin{array}{l}\text { 添 加 量 } \\
\text { (モル数) }\end{array}$ & $\begin{array}{l}\text { 生成物中の含 } \\
\text { 萃(モル\%) }\end{array}$ \\
\hline $\mathrm{S}-2.4-2$ & 0.348 & $1.58 \times 10^{-4}$ & 2 \\
\hline $\mathrm{S}-2.4-10$ & 0.251 & $5.70 \times 10^{-4}$ & 10 \\
\hline$S-4.9-2$ & 0.302 & $1.37 \times 10^{-4}$ & 2 \\
\hline$S-4.9-10$ & 0.275 & $6.24 \times 10^{-4}$ & 10 \\
\hline
\end{tabular}

コールと同一である。これらの試料を用いて行なわれた 熱力学的な研究の結果については次の報告で述へる。

付 婄：本研究は高分子学会第 6 回年次大会 (昭和 32 年 6 月 1 日，東京) で報告した。なお合成について程々有益な 助官をいただいた野間夫之教授に感愔する。

\section{文献}

1) 中島章夫, 石田進, 桜田一郎: 高化, 14, 259(1957)

2) O. Kamm and J.H. Waldo: J. Am. Chem. Soc., 43, 2223(1921)

3) 野間夫之, 加藤晃：私信 (1956)

4) W.L. Ruigh and R.T. Major: J. Am. Chem.Soc., 53, 2662(1931)

5) H. Staudinger: Ber, 67, $1164(1934)$

6) T. Alfrey, J.J. Bohrer and H. Mark: Copolymerization, 176(1951)

7) F.R. Mayo, C. Walling, F.M. Lewis and W.F. Hulse: J. Am. Chem. Soc., 70, 1523(1948)

\title{
Synthesis of Crosslinked Poly(vinyl alcohol) Partially Acetalized with Glyoxylic Acid
}

\author{
By Ichiro Sakurada*, Akio Nakajima* and Hideto Sotobayasi*
}

To discuss the thermodynamic properties of the polyelectrolyte in solution, crosslinked poly(vinyl alcohol) partially acetalized with glyoxylic acid, denoting it by PVAc, was synthesized with the following procedures: vinyl acetate was polymerized under the addition of divinyl ether prepared from ethylene chlorhydrine; the polymerization product was then saponified with sodium hydroxyde; the crosslinked poly(vinyl alcohol) thus obtained was then acetalized with glyoxylic acid. With the method above mentioned, the crosslinked PVAc with the degree of polymerization between adjacent crosslinkages of 500 and 640, containing 0,2 and $10 \mathrm{~mol} \%$ of glyoxylic acid in the chains, were obtained.

* Department of Textile Chemistry, Faculty of Engineering, Kyoto University (Kyoto) 